\title{
Application Programming Interface Google Picker Sebagai Penyimpanan Data Sistem Informasi Arsip Berbasis Cloud
}

\author{
Indra Sontana ${ }^{1}$, Alam Rahmatulloh ${ }^{2}$, Andi Nur Rachman ${ }^{3}$ \\ ${ }^{1,2,3}$ Universitas Siliwangi, Jalan Siliwangi No.24, Kota Tasikmalaya Kode Pos 46115, Indonesia
}

\section{INFORMASI ARTIKEL}

Sejarah Artikel:

Diterima Redaksi: 12 Oktober 2019

Revisi Akhir: 27 Februari 2019

Diterbitkan Online: 30 April 2019

\begin{tabular}{l} 
KATA KUNCI \\
\hline Application Programming Interface \\
Arsip \\
Google Drive \\
Google Picker \\
Sistem Informasi \\
KORESPONDENSI \\
\hline
\end{tabular}

Telepon: +6285223519009

E-mail: alam@unsil.ac.id

\section{A $\quad$ B $\quad \mathbf{S}$ T $\mathbf{R}$ A $\mathbf{C}$ T}

\begin{abstract}
Arsip merupakan salah satu sumber informasi di suatu organisasi baik organisasi pemerintah ataupun organisasi swasta. Dengan semakin berkembangnya perusahaan, penyimpanan arsip akan semakin bertambah banyak, meskipun sudah di simpan ke media penyimpanan fisik seperti harddisk, flashdisk dan server. Penggunaan media penyimpanan dan keamanan menjadi faktor yang mengharuskan perusahaan untuk mengembangkannya lebih jauh. Biaya yang harus dikeluarkan untuk mengembangkan media penyimpanan dan keamanan sangatlah besar terlebih untuk perusahaan yang berskala besar. Dalam penelitian ini solusi yang diambil adalah membuat suatu sistim e-arsip dengan mengimplementasikan cloud storage google drive menggunakan API google picker dimana sebagai media penyimpanan dari sistim tersebut. Sehingga dengan di impementasikannya API google picker sebagai penyimpanan data e-arsip, diharapkan dapat mempermudah dalam melakukan proses penyimpanan data, kemudahan akses data, dapat melakukan penekanan biaya yang harus dikeluarkan untuk pembelian infrastruktur dan software, pengguna dapat melakukan proses simpan dan unduh data secara langsung tanpa membuka aplikasi google drive, dapat memperluas ruang lingkup penyimpanan data tersebut, dan data dapat di unduh secara online ketika pengguna berada di lokasi mana saja dan waktu kapan saja.
\end{abstract}

\section{PENDAHULUAN}

Arsip merupakan salah satu sumber informasi dalam suatu organisasi baik organisasi pemerintah ataupun organisasi swasta yang tentunya memiliki peranan penting dalam kelangsungan hidup perusahaan karena arsip memiliki berbagai informasi yang dapat dijadikan sebagai alat bukti pertanggungjawaban ataupun sebagai alat pendukung dalam mengambil suatu keputusan [1]. Dengan semakin berkembangnya perusahaan, penyimpanan arsip akan semakin bertambah banyak, sehingga data yang terseimpan pada flashdisk, harddisk di server semakin membengkak. Penggunaan media penyimpanan dan keamanan menjadi faktor yang mengharuskan perusahaan untuk mengembangkan lebih jauh. Belum lagi jika penyimpanan pada server clustering dengan konsep load balancing [2], sehingga menjadi masalah baru untuk distribusi harddisk dan biaya yang harus dikeluarkan untuk mengembangkan media penyimpanan dan keamanan sangatlah besar terlebih untuk perusahaan yang berskala besar [3].

Cloud Computing merupakan salah satu alternatif bagi perusahaan untuk menekan biaya-biaya yang menyangkut hal-hal tersebut. Cloud Computing menawarkan penyimpanan virtual yang tidak terbatas dibandingkan server dan hard-drive yang memiliki batas. Ketika membutuhkan ruang penyimpanan yang lebih besar bukanlah menjadi masalah karena perusahaan hanya perlu mengubah layanan penyimpanan ke batas yang lebih besar namun dengan biaya yang berbeda tentunya [3]. Layanan cloud storage merupakan salah satu contoh dari cloud computing. Cloud storage memungkinkan untuk melakukan sinkronisasi folder lokal dengan 
server di awan (internet) [4]. Layanan cloud storage yang digunakan dalam penelitian ini adalah google drive dan fitur yang dimplementasikan adalah Application Programming Interface (API) google picker.

API atau Application Programming Interface merupakan suatu teknologi antarmuka virtual yang memungkinkan untuk bertukar informasi atau data antar aplikasi atau sistim [5]. Google Picker adalah dialog "Buka File" untuk informasi yang disimpan di server Google. Dengan API Google Picker resource yang ada pada server Google dapat dimanfaatkan seperti unggah foto, video, peta dan dokumen [6].

Pada penelitian [7] dan [8] menghasilkan sebuah aplikasi arsip yang bermanfaat dan mampu memberikan kemudahan dalam hal pengelolaan data surat dan berkas, namun pada penelitian tersebut masih menggunakan database lokal sehingga akses data masih terbatas. Penelitian yang akan dilakukan merubah mekanisme penyimpanan lokal tersebut menjadi cloud.

Penelitian selanjutnya [9], [10] dan [11] telah berhasil menerapkan teknologi google drive sebagai model interoperability dalam website berbasis PHP dan penggunaan google drive sebagai penunjang paperless office. Hal tersebut menunjukan bahwa pemanfaatan google drive sebagai penyimpanan cloud dapat mempermudah penyimpanan data dan mengatasi permasalahan interoperability.

Penelitian [3] memberikan gambaran mengenai pengertian cloud computing dan perkembangannya serta keuntungan dan kerugian dari perusahaan yang memanfaatkan teknologi teknologi cloud computing. Berdasarkan penelitian ini diketahui bahwa cloud computing sebagai teknologi yang memanfaatkan layanan internet menggunakan pusat server yang bersifat virtual dengan tujuan pemeliharaan data dan aplikasi. Keberadaan cloud computing sendiri telah menimbulkan perubahan dalam cara kerja sistim teknologi informasi pada sebuah perusahaan. Sistim keamanan dan penyimpanan data menjadi hal yang penting bagi perusahaan. Teknologi cloud computing telah memberikan keuntungan yang besar bagi kebanyakan perusahaan.

Berdasarkan penelitian yang sudah dilakukan tentang bagaimana sebuah google drive itu diimplementasikan sebagai media untuk penyimpanan data, maka akan dilakukan penelitian yang memanfaatkan API google picker untuk proses penyimpanan membuat suatu sistim e-arsip dengan mengimplementasikan cloud storage google drive menggunakan API google picker sebagai media penyimpanan dari sistim tersebut.

Google memiliki keunggulan karena cukup banyak digunakan oleh orang-orang di dunia dengan berbagai jenis layanannya yang sangat beragam seperti Gmail, Google +, Google Drive, Youtube, Google Calendar, dan produk lainnya yang dapat diakses hanya dengan satu akun Google yang sama. Google sangat familiar di mata masyarakat, maka penggunaan Google Drive akan sangat potensial untuk berkembang di masa mendatang, seiring dengan perkembangan teknologi dan ragam produk yang dihasilkan Google
[4]. Adanya media penyimpanan ini dapat membantu dalam melakukan sinkronisasi data antar perangkat, seperti PC dengan smartphone sehingga pengguna cukup mengakses data yang sama dengan menggunakan koneksi internet. Meskipun terdapat beberapa produk sejenis lainnya seperti OneDrive ataupun DropBox. Google Drive Cloud dipilih karena secara tidak langsung sudah menjadi bagian dari Android dimana pengguna cukup menggunakan akun Google saja dan produk ini akan bisa langsung digunakan [4].

Dalam penelitian ini solusi yang diambil adalah membuat suatu sistim e-arsip dengan mengimplementasikan cloud storage google drive menggunakan API google picker dimana sebagai media penyimpanan dari sistim tersebut. Sehingga dengan di impementasikannya API google picker sebagai penyimpanan data e-arsip, diharapkan dapat mempermudah dalam melakukan proses penyimpanan data, kemudahan akses data, dapat melakukan penekanan biaya yang harus dikeluarkan untuk pembelian infrastruktur dan software, pengguna dapat melakukan proses simpan dan unduh data secara langsung tanpa membuka aplikasi google drive, dapat memperluas ruang lingkup penyimpanan data tersebut, dan data dapat di unduh secara online ketika pengguna berada di lokasi mana saja dan waktu kapan saja

\section{METODE}

Kerangka penelitian yang menunjukan bahwa tahap pertama adalah metode pengumpulan data dan tahap kedua metode pengembangan sistim yang dapat dilihat pada Gambar 1 .

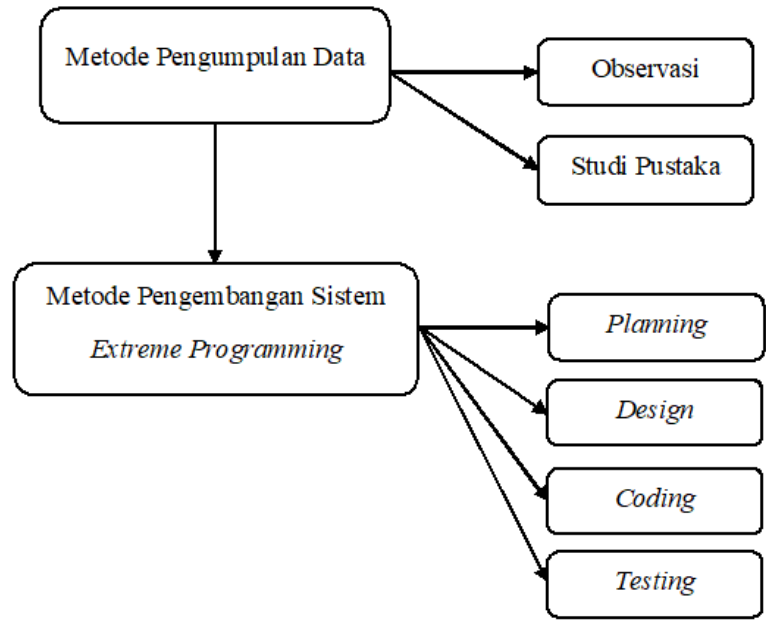

Gambar 1. Kerangka Penelitian

Tahapan-tahapan penelitian dilakukan dengan metode observasi dan studi pustaka. Kemudian data penelitian dikembangkan menggunakan metode pengembangan perangkat lunak Extreme Programming (XP) yang dapat dilihat pada Gambar 2 dengan tahapan Planning, Design, Coding dan Testing. 


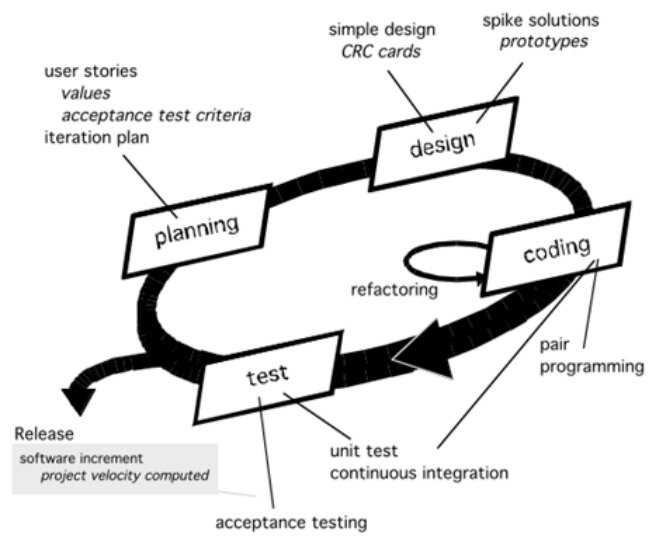

Gambar 2. Kerangka kerja Extreme Programming [12]

\section{HASIL DAN PEMBAHASAN}

\subsection{Pengumpulan Data}

\subsubsection{Observasi}

Hasil observasi mengenai arsip yang didapatkan diantaranya pengarsipan masih ada yang dilakukan secara manual dengan media penyimpanan fisik, namun ada juga yang sudah menggunakan komputer seperti penggunaan arsip dalam file word dan excel sehingga proses penyimpanan atau distribusinya menggunakan harddisk dan flashdisk. Dengan kondisi tersebut permasalahanpermasalahan yang timbul yaitu mengenai distribusi data arsip yang masih terbatas dan belum menerapkan konsep cloud computing. Sehingga pada penelitian ini memanfaatkan API Google Picker agar data arsip dapat disimpan pada server Google.

\subsubsection{Studi Pustaka}

Studi pustaka yang dilakukan dengan cara mencari sumber-sumber dan informasi yang relevan dengan topik penelitian yang akan dilakukan, yaitu diantaranya bersumber dari buku, internet, penelitian dan publikasi ilmiah.

\subsection{Pengembangan Sistim}

\subsubsection{Planning (Perencanaan)}

Penjadwalan pembuatan aplikasi, disajikan pada tabel 1. Dimulai dari minggu ke-empat bulan april sampai dengan bulan september. Tabel 1. Analisis Kebutuhan Data

\begin{tabular}{|c|c|c|c|c|c|c|c|c|c|c|c|c|c|c|c|c|c|c|}
\hline Bulan & April & & $\mathrm{M}_{\mathrm{s}}$ & & & & Jun & & & & Jul & & & & Agus & stus & & September \\
\hline Minggu $\mathrm{Ke}$ & 4 & 1 & 2 & 3 & 4 & 1 & 2 & 3 & 4 & 1 & 2 & 3 & 4 & 1 & 2 & 3 & 4 & \\
\hline Perencanaan & & & & & & & & & & & & & & & & & & \\
\hline Perancangan & & & & & & & & & & & & & & & & & & \\
\hline Pengk & & & & & & & & & & & & & & & & & & \\
\hline Pengujian & & & & & & & & & & & & & & & & & & \\
\hline
\end{tabular}

Tabel 2. Analisis Kebutuhan Data

\begin{tabular}{cl}
\hline \multicolumn{1}{c}{ Nama Data } & \multicolumn{1}{c}{ Atribut } \\
\hline Data Pegawai & Nama, $e$-mail, dan jabatan. \\
\hline Data E-Arsip & $\begin{array}{l}\text { Data dalam bentuk Word, PDF, Excel, Foto } \\
\text { dan Video. }\end{array}$ \\
\hline
\end{tabular}

Tabel 2 merupakan Analisa kebutuhan data arsip berdasarkan standar pengarsipan pada sebuah perusahaan atau perkantoran. Kebutuhan Fungsional aplikasi penyimpanan data e-arsip adalah Sistim menyediakan fitur yang memungkinkan penggunanya memiliki hak akses yang berbeda, sistim dapat menampilkan data pengguna, input data pengguna, menampilkan data e-arsip sesuai dengan hak akses masing-masing pengguna,dan melakukan input data e-arsip.

Spesifikasi minimum perangkat keras yang dibutuhkan untuk dapat menjalankan aplikasi berbasis Web, yaitu: PC yang terhubung dengan jaringan internet, Printer dan Scanner, Selebihnya apikasi ini tidak membutuhkan antarmuka perangkat keras yang spesifik.

\subsubsection{Design (Perancangan)}

Identifikasi aktor akan disajikan dalam bentuk tabel 3 .

Tabel 3. Identifikasi aktor

\begin{tabular}{cl}
\hline Nama Aktor & \multicolumn{1}{c}{ Keterangan } \\
\hline Admin & $\begin{array}{l}\text { Pengguna merupakan administrator yang memiliki hak akses penuh untuk mengelola semua fitur yang ada } \\
\text { pada aplikasi. Hak akses yang diberikan adalah bisa melihat data, menambah data, menghapus data, mencari } \\
\text { data, mengubah data user. }\end{array}$ \\
\hline User/Karyawan & $\begin{array}{l}\text { Pengguna merupakan karyawan yang memiliki hak akses untuk mengolah data e-arsip pada bagian jabatan } \\
\text { yang di pegangnya, bisa melakukan proses pengolahan data seperti menambah data, mencari data, download } \\
\text { data, tetapi terbatas hanya pada bagian jabatan yang di pegangnya. }\end{array}$ \\
\hline
\end{tabular}

Tabel 4. Identifikasi Use Case

\begin{tabular}{ccl}
\hline No & Use Case & \multicolumn{1}{c}{ Fungsi } \\
\hline 1. & Login & $\begin{array}{l}\text { Untuk melakukan validasi atau membedakan login sebagai Admin atau sebagai User dalam } \\
\text { mengakses aplikasi. }\end{array}$ \\
\hline 2. & Data Pengguna & $\begin{array}{l}\text { Untuk melihat semua data pengguna, dan dapat menambahkan, mengedit atau menghapus data } \\
\text { pengguna, admin harus login terlebih dahulu. }\end{array}$ \\
\hline
\end{tabular}




\begin{tabular}{ccl}
\hline 3. Data & Admin dapat menyimpan, mendownload, mencari, mencetak, menghapus dan mengedit semua data \\
E-Arsip & $\begin{array}{l}\text { e-arsip yang di inputkan oleh user. Sedangkan User hanya dapat menyimpan, mendownload, } \\
\text { mencari, mencetak dan mengedit data e-arsip sesuai dengan hak akses masing-masing user. } \\
\end{array}$ & Pengguna harus login terlebih dahulu. \\
\hline $4 . \quad$ Google Drive & Database dari penyimpanan Data E-Arsip \\
\hline
\end{tabular}

Identifikasi Use Case disajikan dalam bentuk tabel 4.

Use Case Diagram disajikan dalam bentuk gambar 3.

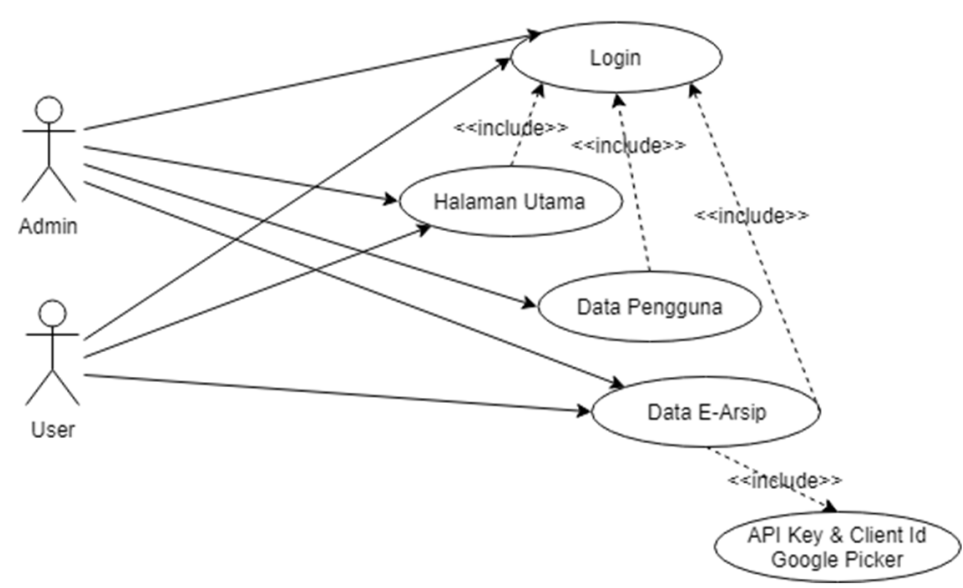

Gambar 3. Use Case Diagram

Skenario use case disajikan dalam bentuk tabel 5 sampai dengan tabel 6.

Tabel 5. Skenario Use Case Login

\begin{tabular}{lll}
\hline ID & $:$ & 1.1 \\
Nama Use Case & $:$ & Login \\
Aktor & $:$ & Pengguna \\
Tujuan Keputusan & $:$ & Pengguna telah mengakses aplikasi namun \\
& & belum masuk ke menu aplikasi \\
Deskripsi & $:$ & $\begin{array}{l}\text { Pengguna memasukan username dan } \\
\text { password untuk mengakses menu aplikasi } \\
\end{array}$ \\
& sesuai hak akses pengguna. \\
\hline
\end{tabular}

\begin{tabular}{|c|c|}
\hline Aksi Aktor & Reaksi Sistim \\
\hline \multirow[t]{2}{*}{$\begin{array}{l}\text { 1. Pengguna mengisi form } \\
\text { login dengan memasukkan } \\
\text { username dan password } \\
\text { lalu menekan tombol login }\end{array}$} & \\
\hline & $\begin{array}{l}\text { 2. Melakukan verifikasi } \\
\begin{array}{l}\text { username dan password yang } \\
\text { dimasukkan oleh pengguna }\end{array}\end{array}$ \\
\hline \multicolumn{2}{|l|}{$\begin{array}{l}\text { 3. Memasukan username dan } \\
\text { password yang tidak valid }\end{array}$} \\
\hline & $\begin{array}{l}\text { 4enampilkan informasi } \\
\text { kesalahan login tidak valid }\end{array}$ \\
\hline \multicolumn{2}{|l|}{$\begin{array}{l}\text { 5. Memasukan username dan } \\
\text { password yang valid }\end{array}$} \\
\hline & $\begin{array}{l}\text { 6. Memeriksa valid tidaknya } \\
\text { username dan password yang } \\
\text { dimasukkan }\end{array}$ \\
\hline & $\begin{array}{l}\text { 7. Menampilkan halaman utama } \\
\text { dan menu aplikasi sesuai } \\
\text { dengan hak akses yang } \\
\text { diberikan. }\end{array}$ \\
\hline
\end{tabular}

Tabel 6. Skenario Use Case Data E-Arsip

\begin{tabular}{lll}
\hline ID & $:$ & 1.2 \\
Nama Use Case & $:$ & Data E-Arsip \\
Aktor & $:$ & Pengguna \\
Tujuan Keputusan & $:$ & Pengguna memilih menu Data E-Arip \\
Deskripsi & $:$ & Admin melihat data e-arsip yang tersimpan \\
& dalam aplikasi secara keseluruhan, \\
& $\begin{array}{l}\text { sedangkan User melihat data e-arsip sesuai } \\
\text { dengan hak aksesnya masing-masing. }\end{array}$ \\
\hline
\end{tabular}

Aksi Aktor Reaksi Sistim

1. Memilih menu data earsip.

2. Menampilkan halaman popup data e-arsip sesuai dengan hak akses masing-masing pengguna.

\begin{tabular}{llll}
\hline 3. Memilih tombol Upload & & & \\
\hline & 4. & $\begin{array}{l}\text { Menampilkan menu upload } \\
\text { data e-arsip }\end{array}$ & \\
\hline
\end{tabular}

\begin{tabular}{lll}
\hline 5. & $\begin{array}{l}\text { Klik "Select files from } \\
\text { your computer" / Drag } \\
\text { file data e-arsip yang } \\
\text { akan disimpan, klik } \\
\text { tombol Upload }\end{array}$ & \\
\hline & 6. & $\begin{array}{l}\text { Menambah dan menyimpan } \\
\text { data penguna ke Google } \\
\text { Drive. }\end{array}$ \\
\hline & 7. & $\begin{array}{l}\text { Menampilkan halaman data e- } \\
\text { arsip, data bertambah dan } \\
\text { berhasil disimpan. }\end{array}$ \\
\hline 8. & $\begin{array}{l}\text { Memilih file yang akan } \\
\text { di lihat isinya, double } \\
\text { klik/klik select }\end{array}$ & \\
\hline & 9. & $\begin{array}{l}\text { Menampilkan halaman popup } \\
\text { isi file. }\end{array}$ \\
\hline 10. & Memilih tombol cetak & \\
\hline & 11. & $\begin{array}{l}\text { Menampilkan halaman cetak } \\
\text { data e-arsip }\end{array}$ \\
\hline 12. & Memilih tombol \\
download & \\
\hline
\end{tabular}


13. Menyimpan data e-arsip ke Komputer/Laptop

\begin{tabular}{ll}
\hline $\begin{array}{l}\text { Memilih tombol "Buka } \\
\text { dengan } \\
\text { Dokumen" }\end{array}$ & \\
\hline
\end{tabular}

15. Menampilkan data e-arsip di halaman google dokumen

\section{Memilih tombol Bagikan}

17. Menampilkan popup form "bagikan dengan orang lain", masukkan nama atau alamat email, dan memberikan pilihan hak akses : Dapat mengedit, Dapat komentar, Dapat melihat

18. Memilih tombol Atur

19. Menampilkan popup pilihan folder yang akan di atur

Class diagram disajikan dalam bentuk gambar 4

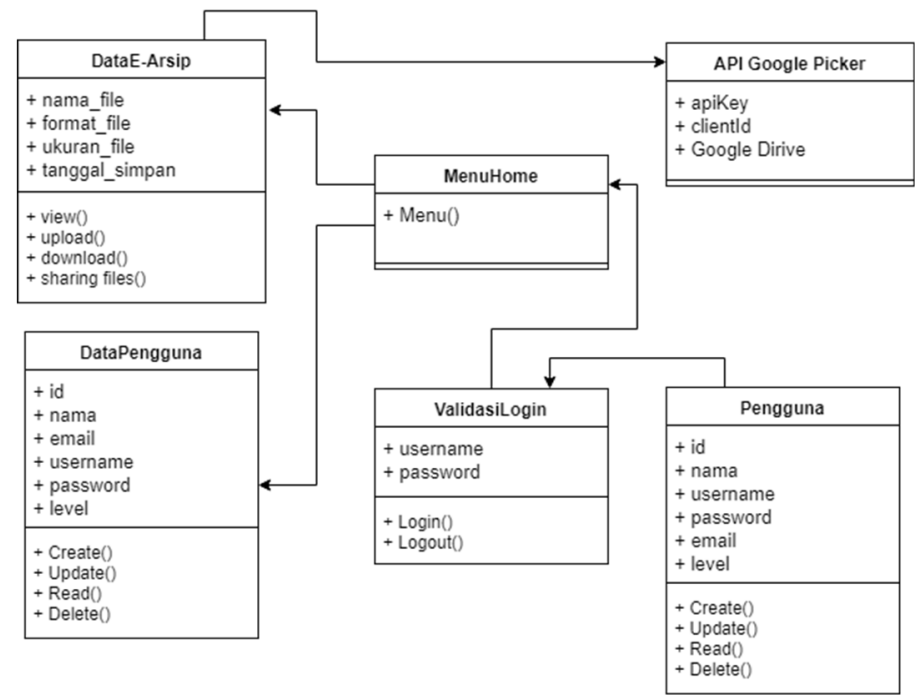

Gambar 4. Use Case Diagram

CRC Card disajikan dalam bentuk tabel 7.

Tabel 7. CRC Card Menu Utama

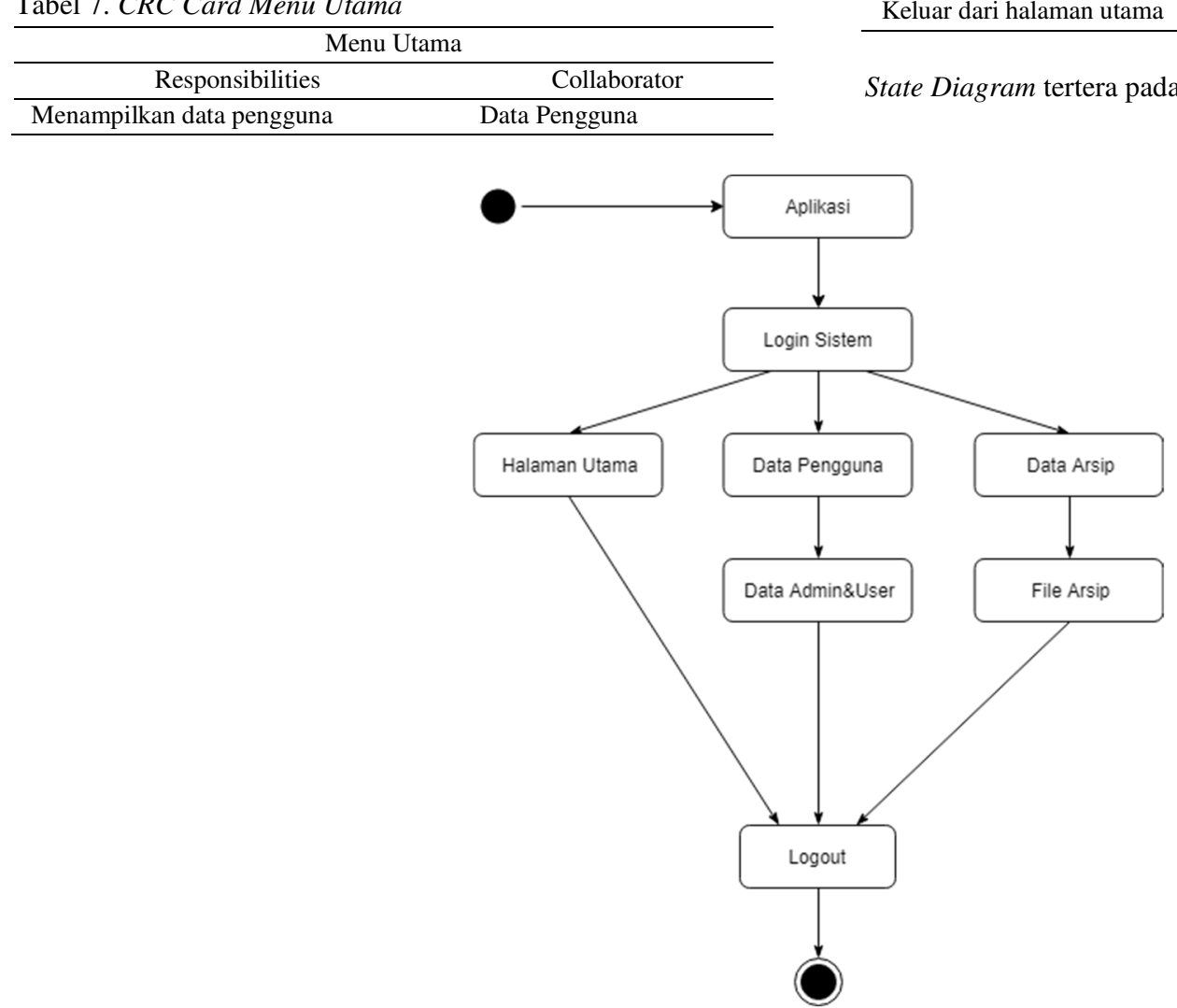

Gambar 5. State Diagram

Perancangan Antarmuka (Interface) disajikan dalam bentuk gambar 6 sampai dengan gambar 8 . 


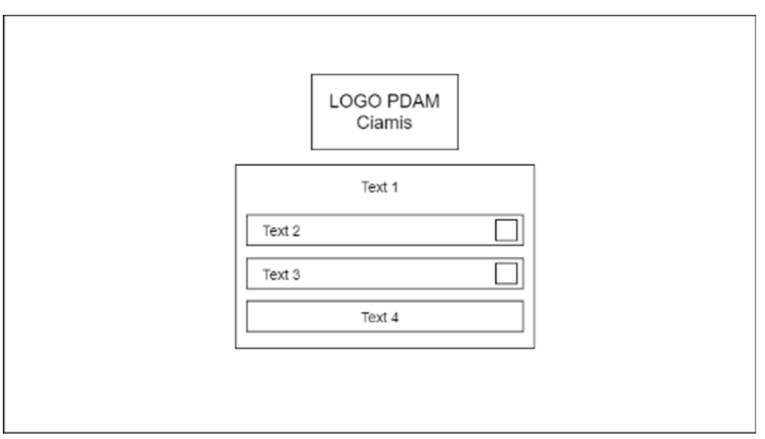

Gambar 6. Perancangan antarmuka halaman login

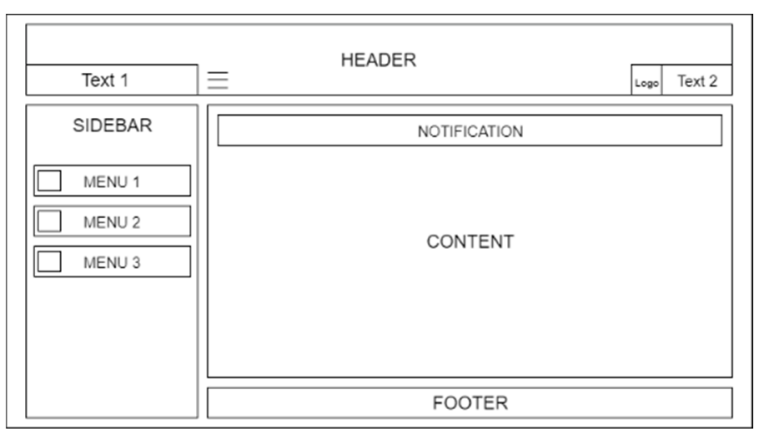

Gambar 7 Perancangan antarmuka halaman utama

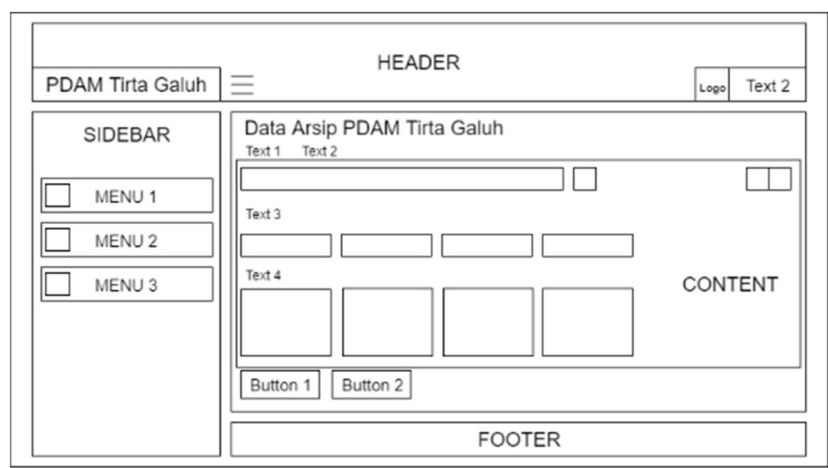

Gambar 8. Perancangan antarmuka menu data e-arsip

\subsubsection{Coding(Pengkodean)}

a. Source code

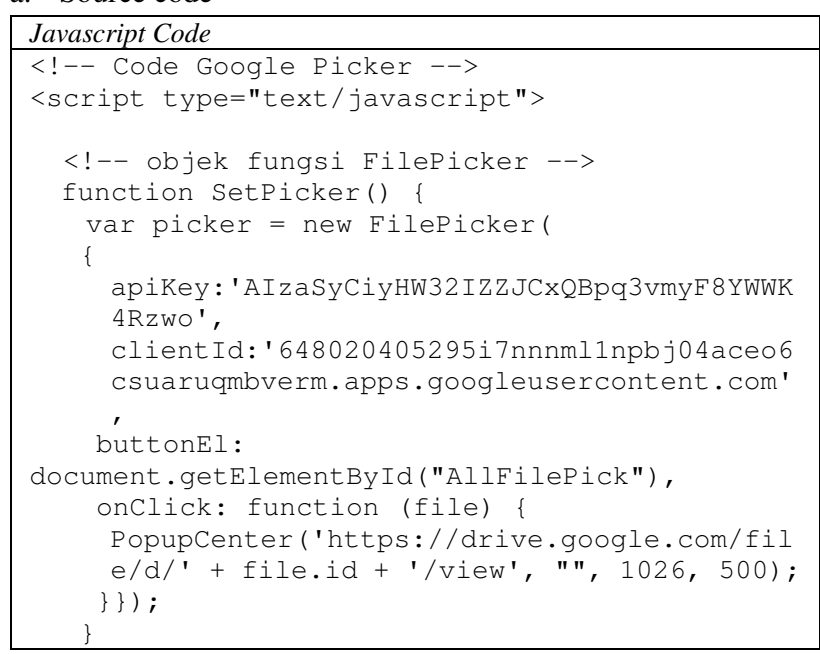

Gambar 9. Potongan Source code data e-arsip admin

Source Code pada gambar 9 merupakan proses pemanggilan dan verifikasi API Key dan Client ID Google Picker. Untuk source code Data E-Arsip User sama dengan Admin, hanya dibedakan di

30 Indra Sontana pemanggilan dokumen atau folder dari google drive. Dokumen atau folder tersebut akan di tampilkan di halaman Data E-Arsip.

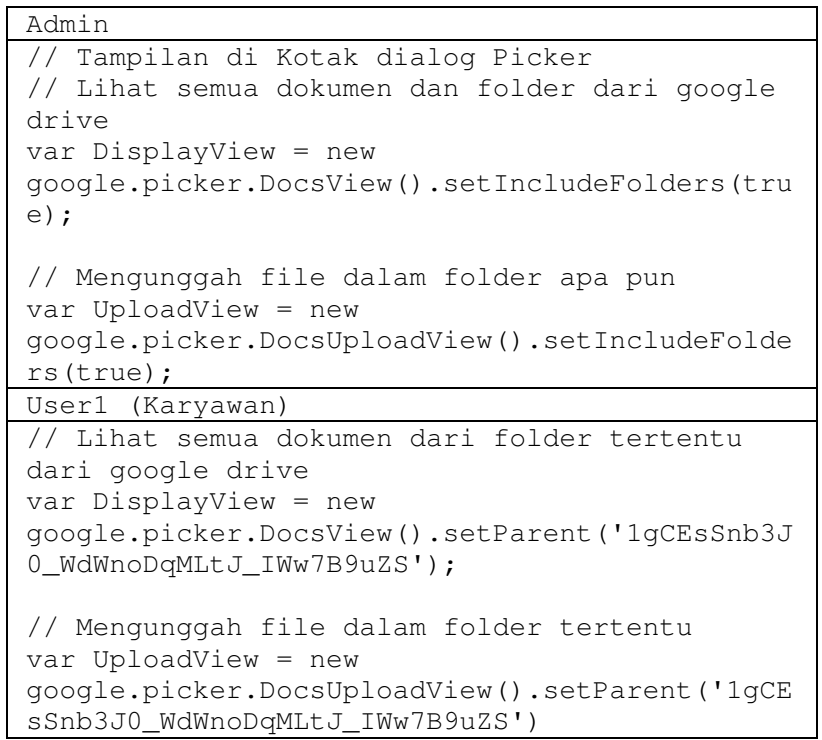

Gambar 10. Source code untuk mengatur perbedaan hak akses antara admin \& user.

Source Code pada gambar 10 merupakan proses pengambilan dokumen dan folder dari google drive dan untuk mengatur hak akses admin \& user. Untuk source code data e-arsip user 2 , user3, user4 sama dengan userl, hanya dibedakan di pemanggilan dokumen atau folder dari google drive. Dokumen atau folder tersebut akan di tampilkan di halaman Data E-Arsip.

b. Implementasi Aplikasi

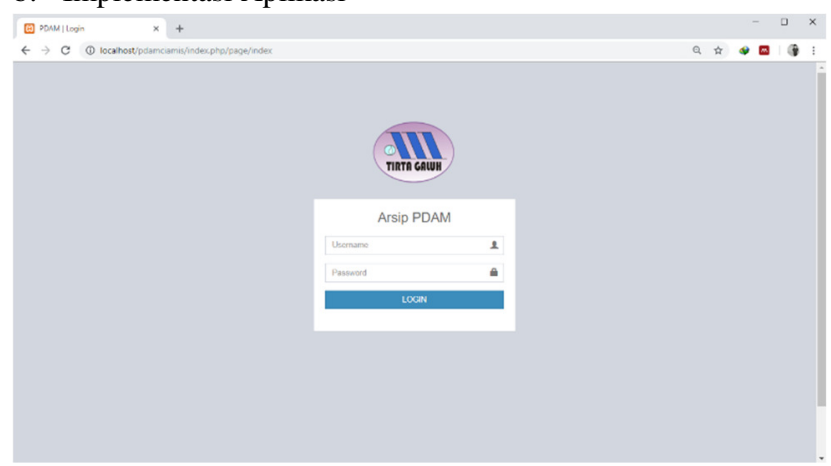

Gambar 11. Tampilan Menu Login

Gambar 11. merupakan tampilan menu login. Pengguna harus mengisi form login dengan username dan password yang sesuai dengan database, kemudian akan diarahkan ke halaman utama sesuai dengan hak aksesnya.

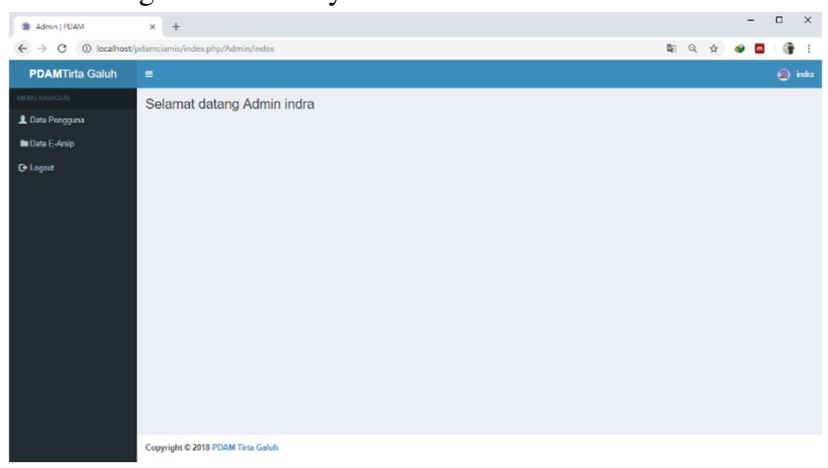

Gambar 12. Halaman Utama Level Admin

Gambar 12. merupakan tampilan halaman utama level admin. Admin mempunyai hak akses untuk mengelola semua fitur yang 
ada pada aplikasi. Pada halaman utama level admin menampilkan menu data pengguna, data e-arsip dan logout. Sedangkan untuk halaman utama level user, hak akses user dibatasi hanya dapat melakukan pengolahan data e-arsip. Pada halaman utama level user menampilkan menu data e-arsip dan logout.

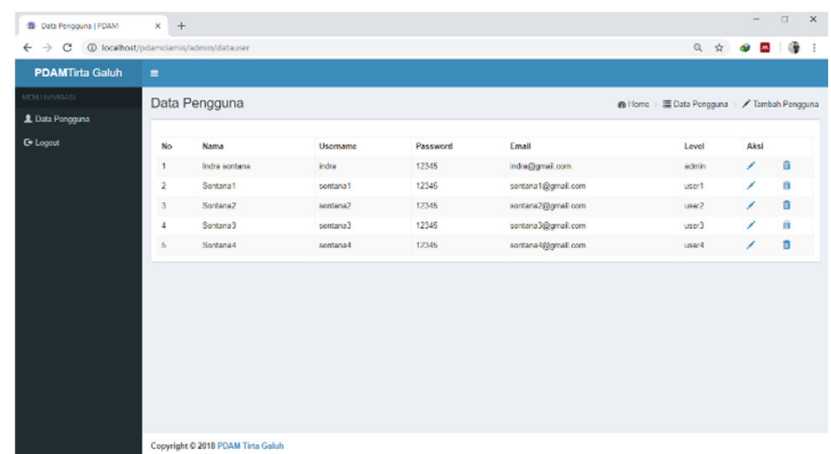

Gambar 13. Halaman Data Pengguna

Gambar 13. merupakan halaman untuk pengelolaan data pengguna, dimana pada halaman tersebut menampilkan data pengguna yang telah diberikan hak akses masing-masing dan tersimpan pada database, pada halaman ini terdapat tomboltombol untuk melakukan proses tambah pengguna, edit, dan hapus data penggguna. Halaman data pengguna hanya dapat diakses oleh Admin.

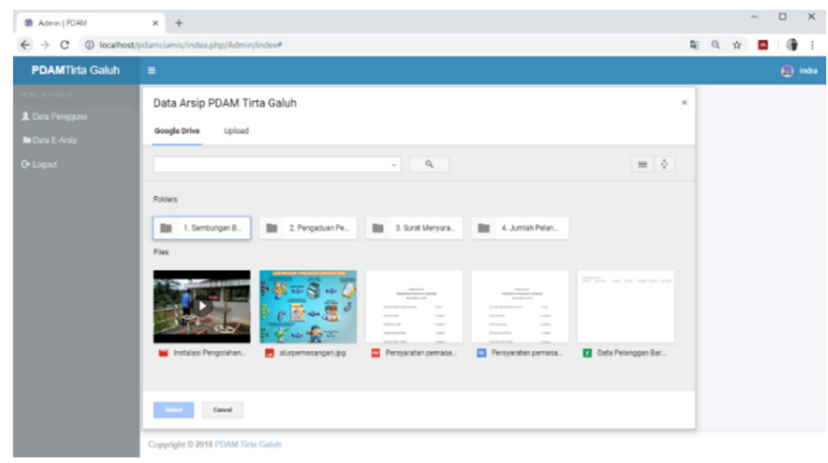

Gambar 14. Halaman Data E-Arsip Level Admin

Gambar 14. merupakan halaman untuk melihat data e-arsip level admin. Admin bisa melihat dan mengunggah semua dokumen atau folder semua karyawan. Pada halaman ini terdapat tomboltombol untuk melakukan cari data, mengurutkan data, detail data, upload, download, dan share data.

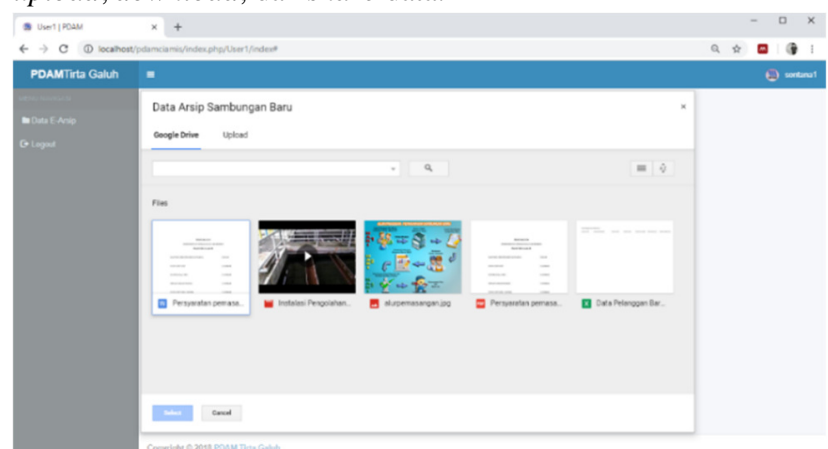

Gambar 15. Halaman Data E-Arsip Level User

Gambar 15. merupakan halaman untuk melihat data e-arsip level user. Hak akses user dibatasi hanya bisa melihat folder tertentu dan mengunggah file dalam folder tertentu sesuai bagian masingmasing user. Pada halaman ini terdapat tombol-tombol untuk melakukan cari data, mengurutkan data, detail data, upload, download, dan share data.
Tabel 8. Pengujian Menu Login

\begin{tabular}{|c|c|c|c|c|}
\hline $\begin{array}{c}\text { No } \\
\text { Pros } \\
\text { es } \\
\end{array}$ & $\begin{array}{c}\text { Langkah } \\
\text { Pengujian }\end{array}$ & $\begin{array}{c}\text { Hasil Yang } \\
\text { Diharapkan }\end{array}$ & $\begin{array}{c}\text { Hasil } \\
\text { Pengujian }\end{array}$ & $\begin{array}{c}\text { Respon } \\
\text { Program }\end{array}$ \\
\hline A1 & $\begin{array}{l}\text { Nama } \\
\text { Pengguna dan } \\
\text { Kata Sandi, } \\
\text { salah satu atau } \\
\text { keduanya } \\
\text { kosong }\end{array}$ & $\begin{array}{l}\text { Menampilkan } \\
\text { pesan gagal } \\
\text { login }\end{array}$ & $\begin{array}{l}\text { Menampilkan } \\
\text { pesan Harap } \\
\text { isi bidang ini. }\end{array}$ & Berhasil \\
\hline A2 & \begin{tabular}{l}
\multicolumn{2}{l}{ Nama } \\
Pengguna dan \\
Kata Sandi \\
salah satunya \\
salah
\end{tabular} & $\begin{array}{l}\text { Menampilkan } \\
\text { pesan gagal } \\
\text { login }\end{array}$ & $\begin{array}{l}\text { Menampilkan } \\
\text { pesan } \\
\text { Username } \\
\text { atau } \\
\text { Password } \\
\text { tidak sesuai }\end{array}$ & Berhasil \\
\hline A3 & $\begin{array}{l}\text { Nama } \\
\text { Pengguna dan } \\
\text { Kata Sandi } \\
\text { terisi dengan } \\
\text { benar }\end{array}$ & $\begin{array}{l}\text { Menampilkan } \\
\text { form menu } \\
\text { utama, sesuai } \\
\text { hak akses } \\
\text { masing- } \\
\text { masing }\end{array}$ & $\begin{array}{l}\text { Menampilkan } \\
\text { form menu } \\
\text { utama, sesuai } \\
\text { hak akses } \\
\text { masing- } \\
\text { masing }\end{array}$ & Berhasil \\
\hline
\end{tabular}

Tabel 9. Pengujian Menu Data E-Arsip

\begin{tabular}{|c|c|c|c|c|}
\hline $\begin{array}{c}\text { No } \\
\text { Pros } \\
\text { es }\end{array}$ & $\begin{array}{l}\text { Langkah } \\
\text { Pengujian }\end{array}$ & $\begin{array}{l}\text { Hasil Yang } \\
\text { Diharapkan }\end{array}$ & $\begin{array}{c}\text { Hasil } \\
\text { Pengujian }\end{array}$ & $\begin{array}{c}\text { Respon } \\
\text { Program }\end{array}$ \\
\hline $\mathrm{B} 1$ & $\begin{array}{l}\text { Pengguna } \\
\text { memilih } \\
\text { menu Data } \\
\text { E-Arsip }\end{array}$ & $\begin{array}{l}\text { Menampilkan } \\
\text { Data E-Arsip } \\
\text { sesuai hak akses } \\
\text { pengguna }\end{array}$ & $\begin{array}{l}\text { Aplikasi } \\
\text { menampilkan } \\
\text { menu Data E- } \\
\text { Arsip sesuai } \\
\text { hak akses } \\
\text { pengguna }\end{array}$ & Berhasil \\
\hline B2 & $\begin{array}{l}\text { Memilih } \\
\text { menu } \\
\text { "upload" }\end{array}$ & $\begin{array}{l}\text { Menampilkan } \\
\text { form upload } \\
\text { data e-arsip }\end{array}$ & $\begin{array}{l}\text { Aplikasi } \\
\text { menampilkan } \\
\text { form upload } \\
\text { data e-arsip }\end{array}$ & Berhasil \\
\hline B3 & $\begin{array}{l}\text { Ditambahka } \\
\mathrm{n} \text { data e- } \\
\text { arsip baru, } \\
\text { Klik tombol } \\
\text { "upload" }\end{array}$ & $\begin{array}{l}\text { Menyimpan } \\
\text { data e-arsip baru }\end{array}$ & $\begin{array}{l}\text { Data e-arsip } \\
\text { disimpan dan } \\
\text { menampilkan } \\
\text { data e-arsip }\end{array}$ & Berhasil \\
\hline B4 & $\begin{array}{l}\text { Pilih file e- } \\
\text { arsip, double } \\
\text { klik/ klik } \\
\text { tombol } \\
\text { select }\end{array}$ & $\begin{array}{l}\text { Menampilkan } \\
\text { isian file e-arsip }\end{array}$ & $\begin{array}{l}\text { Menampilkan } \\
\text { popup halaman } \\
\text { isian file e- } \\
\text { arsip. }\end{array}$ & Berhasil \\
\hline B5 & $\begin{array}{l}\text { Memilih } \\
\text { tombol } \\
\text { "cetak" }\end{array}$ & $\begin{array}{l}\text { Menampilkan } \\
\text { halaman cetak } \\
\text { data e-arsip }\end{array}$ & $\begin{array}{l}\text { Menampilkan } \\
\text { halaman cetak } \\
\text { data e-arsip }\end{array}$ & Berhasil \\
\hline B6 & $\begin{array}{l}\text { Memilih } \\
\text { tombol } \\
\text { "download" }\end{array}$ & $\begin{array}{l}\text { Menyimpan } \\
\text { data e-arsip ke } \\
\text { direktori } \\
\text { pc/laptop }\end{array}$ & $\begin{array}{l}\text { Menyimpan } \\
\text { data e-arsip ke } \\
\text { direktori } \\
\text { pc/laptop }\end{array}$ & Berhasil \\
\hline B7 & $\begin{array}{l}\text { Memilih } \\
\text { tombol } \\
\text { "Bagikan" }\end{array}$ & $\begin{array}{l}\text { Menampilkan } \\
\text { popup form isian }\end{array}$ & $\begin{array}{l}\text { Menampilkan } \\
\text { popup form } \\
\text { isian } \\
\text { "masukkan } \\
\text { nama/email }\end{array}$ & Berhasil \\
\hline B8 & $\begin{array}{l}\text { Pilih file e- } \\
\text { arsip, double } \\
\text { klik, klik } \\
\text { tombol } \\
\text { "Buka } \\
\text { dengan } \\
\text { Google } \\
\text { Dokumen" }\end{array}$ & $\begin{array}{lr}\text { Mengubah } & \text { data } \\
\text { yang } & \text { telah } \\
\text { disimpan } & \\
\text { sebelumnya } & \end{array}$ & $\begin{array}{l}\text { Data berhasil di } \\
\text { ubah dan telah } \\
\text { update. }\end{array}$ & Berhasil \\
\hline
\end{tabular}




\subsubsection{Testing(Pengujian)}

Metode yang digunakan dalam pengujian sistim adalah pengujian black-box. Pengujian sistim disajikan dalam bentuk tabel 8 sampai dengan tabel 9 .

Hasil penelitian memiliki kelebihan diantaranya:

1. Aplikasi ini tidak memerlukan media penyimpanan khusus, otomatis memanfaatkan layanan cloud storage google drive.

2. Penggunaan teknologi cloud storage membantu perusahaan melakukan penekanan biaya yang harus dikeluarkan untuk pembelian infrastruktur dan software.

Sedangkan kekurangan dari hasil penelitian ini aspek keamanan aplikasi masih rentan karena hanya memasukan nama pengguna dan kata sandi dalam hak aksesnya.

\section{KESIMPULAN}

Berdasarkan hasil dari penelitian ini, didapatkan kesimpulan dari aplikasi E-Arsip, yaitu:

1. Penggunaan Application Programming Interface Google Picker telah berhasil mengintegrasikan sistim arsip dengan server google sehingga yang dapat melakukan proses akses, simpan dan unggah data e-arsip pada cloud google.

2. Dengan adanya fasilitas cloud storage google drive membantu perusahaan dalam menghemat dan menangani keterbatasan harddisk dan server, serta memudahkan dalam proses distribusi data arsip.

Untuk pengembangan aplikasi penyimpanan data e-arsip ini, disarankan untuk menerapkan API google pada layanan lain, untuk diterapkan pada aplikasi E-Arsip ini, seperti layanan login otomatis dengan email google, layanan kalender untuk pengingatnya.

\section{DAFTAR PUSTAKA}

[1] E. Nanda, Perancangan Sistem Kearsipan Elektronik Dengan Menggunakan Aplikasi Microsoft Access 2007 Di Bagian Perencanaan Pada Pdam Tirta Musi Palembang, 2016.

[2] A. Rahmatulloh dan F. MSN, "Implementasi Load Balancing Web Server menggunakan Haproxy dan Sinkronisasi File pada Sistem Informasi Akademik Universitas Siliwangi," Jurnal Teknologi dan Sistem Informasi, vol. 3, no. 2, 2017.

[3] J. Tandy dan Siswono, "Cloud Computing Dan Dampaknya Terhadap Bisnis," ComTech, vol. 4, no. 2, 2013.

[4] A. Juliandi, "Teknologi Cloud Personal Storage Dengan Google Drive: Membangun Budaya Kerja Online,” 2014.

[5] S. P. Ong, S. Cholia, A. Jain, M. Brafman, D. Gunter, G. Ceder dan K. A. Persson, "The Materials Application Programming Interface (API): A simple, flexible and efficient API for materials data based on REpresentational State Transfer (REST) principles," Computational Materials Science, vol. 97, 2015.
[6] Google, "Google Picker," Google, [Online]. Available: https://developers.google.com/picker/. [Diakses 201 2019].

[7] E. R. Subhiyakto, Y. P. Astuti, L. Umaroh, D. W. Utomo, E. H. Rachmawanto dan C. A. Sari, "Rancang Bangun Sistem Informasi Pengarsipan Data Pasien Klinik Cemara," Jurnal Teknologi Informasi, vol. 16, no. 1, 2017.

[8] D. Yudhianto, "MEMBANGUN APLIKASI E-ARSIP SEBAGAI MEDIA PENYIMPANAN BERBASIS WEBSITE (Studi Kasus: CV Lusi Contractor Semarang)," Doctoral dissertation, Universitas Teknologi Yogyakarta, 2017.

[9] O. S. NINGRUM, "PENGGUNAAN APLIKASI GOOGLE DRIVE SEBAGAI PENUNJANG PAPERLESS OFFICE," Jurnal Administrasi Perkantoran (JPAP), vol. 3, no. 3, 2015.

[10] A. Nugroho, A. D. Cahyono dan A. D. Utomo, "Rancang Bangun Aplikasi Digital Watermarking untuk Pengamanan Citra Digital pada Google Drive Cloud Berbasis Android," Universitas Kristen Satya Wacana, Salatiga, 2016.

[11] N. K. Sumiari, "Pemanfaatan Google API untuk Model Interoperability Web Berbasis PHP dengan Google Drive," Jurnal Sistem dan Informatika (JSI), vol. 10, no. 1, 2015.

[12] R. S. Pressman, Rekayasa Perangkat Lunak (Pendekatan Praktisi) Edisi 7, Andi Offset, 2012.

\section{BIODATA PENULIS}

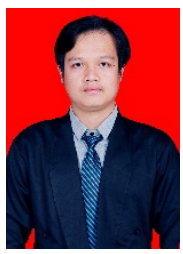

Indra Sontana

Lahir di Tasikmalaya, 11 Mei 1996, mahasiswa Teknik Informatika, Universitas Siliwangi

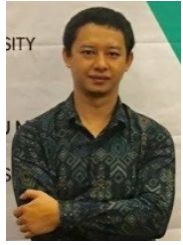

Alam Rahmatulloh

Dosen di Jurusan Teknik Informatika, Universitas Siliwangi

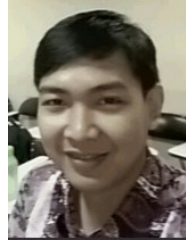

Andi Nur Rachman

Dosen di Jurusan Teknik Informatika, Universitas Siliwangi 